\title{
CLASS CULTURE AND THE ACADEMIC STRESS OF DIGITAL NATIVES GENERATIONS
}

\author{
Binti Muchsini*, Siswandari \\ Universitas Sebelas Maret Surakarta, Indonesia \\ *e-mail: binti_muchsini@staff.uns.ac.id
}

\begin{abstract}
The culture Digital Natives Generations (DNG) are important considerations for lecturers in designing their courses because they are a generation that is very familiar with the technology. The DNG will feel pressured if the learning process is similar to that of the previous generation. Therefore, the purpose of this study is to examine the effect of cultural values in the classroom that may lead to the academic stress of DNG. The research uses quantitative research methods. The instruments of cultural values in the classroom refer to Hofstede's cultural dimension, while Academic Stress (AS) refers to Gadzella's Student-Life Stress Inventory, with 152 respondents representing students at Sebelas Maret University Indonesia. Data analysis was performed using simple regression analysis with the aid of MINITAB. The results show that there are significant influence of cultural values in the classroom Power Distance (PD), collectivism individualism (CI), feminism masculinity (FM), uncertainty avoidance (UAI), and long-term orientation (LTO) on AS $(\mathrm{p}<0.05)$. The results of the study could be utilized to determine the cultural values in the classroom that could be incorporated into the design of learning models so as to minimize the AS of DNG at higher education.
\end{abstract}

Keywords: culture values, academic stress, digital natives

\section{BUDAYA KELAS DAN STRES AKADEMIK GENERASI BAWAAN DIGITAL}

Abstrak: Budaya Generasi Bawaan Digital (GBD) menjadi pertimbangan yang penting bagi dosen dalam mendesain pembelajarannya karena generasi tersebut sangat familier dengan teknologi. GBD akan merasa tertekan apabila proses pembelajarannya disamakan dengan generasi sebelumnya. Tujuan penelitian ini adalah untuk menguji pengaruh nilai-nilai budaya didalam kelas yang terhadap stres akademik GBD. Penelitian ini menggunakan metode penelitian kuantitatif. Instrumen nilai-nilai budaya di dalam kelas mengacu pada dimensi budaya Hofstede sedangkan Stres Akademik (SA) mengacu pada Gadzella's Student-Life Stress Inventory dengan responden 152 mahasiswa Universitas Sebelas Maret, Indonesia. Analisis data menggunakan analisis regresi sederhana dengan bantuan Minitab. Hasil menunjukkan bahwa terdapat pengaruh yang signifikan antara nilai-nilai budaya di dalam kelas Power Distance (PD), collectivism individualism (CI), feminism masculinity (FM), uncertainty avoidance (UAI), and long-term orientation (LTO) terhadap SA $(\mathrm{p}<0.05)$. Hasil penelitian ini dapat dimanfaatkan dalam menentukan nilai-nilai budaya di dalam kelas yang akan disisipkan dalam mendesain model pembelajaran sehingga mampu meminimalisir stres akademik GBD pada mahasiswa.

\section{Kata Kunci: nilai-nilai budaya, stres akademik, bawaan digital}

\section{INTRODUCTION}

The students currently studying at college are of the generation born after 1980, who are referred to as the digital native generation (DNG) (Prensky, 2001), millennials (Lancaster \& Stillman, 2002), or the net generation (Sandars, \& Morrison, 2007). On the otherhand, $90 \%$ of lecturers were born before 1980 , so they belong to the digital immigrant generation (DIG) (Prensky, 2001). The two generations have different cultures because the DNG is a new cultural product resulting from the penetration of digital technology (Kivunja, 2014), for them, technology is like air (Tapscott, 2009), while the DIG was born when technology was still very limited (Prensky, 2001).

The DNG has different ways of thinking, learning habits and language than the DIG (Prensky, 2001; Kivunja, 2014). It has the habit of learning in a fun and flexible way and can learn 
while listening to music or even while chatting, so it is impossible to force them to learn in the old-fashioned way because their brain structures are different from those of previous generations. The DNG will quickly become bored if using traditional learning methods, while the DIG does not believe that a person can learn successfully while watching TV or listening to music because digital immigrants are unable to employ such learning habits (Prensky, 2001).

These different patterns of thinking and learning habits show the cultural differences between the two generations during the learning process. Culture is key to the success of a nation's development (Rochmat, 2018); it refers to values, principles, traditions and habits (Sarjou, Soltani, Kalbasi, \& Mahmoudi, 2012; Muslimin, 2018). Following Hofstede \& Bond (1984) have identified for environment cultures in educational systems, such as schools and universities consists of five dimensions, namely power distance (PD), collectivism individualism (CI), feminism masculinity (FM), uncertainty avoidance (UAI), and long-term orientation (LTO). High PD does not give freedom to individuals to do things according to their wishes or to make their own decisions (Joy \& Kolb, 2009).

In the classroom, high PD is indicated by the misalignment between teachers and students; in other words, teachers do not allow freedom for students to develop their creative ideas, or there is a tendency for teacher-centred learning (Hofstede $\&$ Bond, 1984). CI shows individual discretion in making choices about the importance of group and individual interests (Hofstede \& Bond, 1984). The results of the study of Kormi-Nouri, MacDonald, Farahani, Trost, \& Sokri (2015) indicate that there are differences in academic stress (AS) between students and cultures that tend towards individualism and collectivism; students whose culture tends to be individualist show a higher AS than those whose culture is more collectivist. FM shows whether there are differences in the views or thoughts of men and women (Hofstede \& Bond, 1984). Masculinity culture considers the performance and thinking of men better than women (Pekkarinen, 2008).

The culture affects the mental and emotional condition of women. Some studies even have found that women experience a higher AS than men (Kormi-Nouri et al., 2015;
McDaniel, 2010; Pekkarinen, 2008). UAI is an individual's attitude to facing change (Hofstede \& Bond, 1984). In the academic environment, high UAI is indicated by a sense of comfort in a structured learning situation (Joy \& Kolb, 2009), and if is only one correct answer (Hofstede, 2001), while low UAI is indicated by a sense of comfort in an open learning situation where there is room for ideas, and the chance to learn from real experience and active experiments (Joy \& Kolb, 2009). LTO is individuals' thinking about the consequences of their actions (Hofstede \& Bond, 1984), so that they make plans using their cognitive abilities, consider everything when starting new tasks, are willing to take risks in trying new things and do not easily give up (Joy \& Kolb, 2009), and are innovative and tolerant of change (House, Hanges, Javidan, Dorfman, \& Gupta, 2004).

Cultural differences in the classroom will have a significant impact, such as creating a sense of pressure in each individual. Individuals are part of the culture in which they are located, and culture has a significant effect on the process of adjustment of each individual in the surrounding environment (Gundus, Aktepe, Sulak, Baspinar, \& Buyukkarci, 2019). In the academic environment, the stress caused by cultural differences is known as academic stress; stress is a by-product of achievement due to the ongoing culture (Mrowka, 2014). It is a part of every person's life that cannot be avoided; according to Shankar \& Park (2016), stress is a process of the relationship between people and their environment. It occurs because individuals feel unable to face their environmental demands (Lazarus \& Folkman, 1984). Therefore, AS is a perception related to the demands of the academic environment compared to one's ability to overcome them. The impact will cause pressure on individuals (Lazarus \& Folkman, 1984), which will be dangerous to their physical and mental condition (Gaol, 2016). In the academic environment, one's academic ability will tend to decrease (Talib \& Zia-ur-Rehman, 2012; Goff, 2011).

Understanding cultural values will affect the achievement of national educational goals, which contain cultural values (Gufron, Budiningsih, \& Hidayati, 2017; Gundus et al., 2019); therefore, it is very important to identify the cultural values present within classes that cause digital natives to 
feel depressed or to experience AS. Knowledge of the source of the causes of academic stress derived from cultural values in the classroom can be used to determine the values that should be utilized in designing learning models so as to minimize the academic stress of DNG students at higher education. The purpose of this study is to examine the effect of cultural values in the classroom that may lead to the academic stress of Digital Natives Generations.

\section{METHODS}

This research design used a quantitative approach that aims to explain the cultural values in the classroom that affect the AS of DNG in Sebelas Maret University, Indonesia. The instrument used to collect the data related to class cultural values and academic stress was a questionnaire, with each variable consisting of 15 valid statement items. The questionnaire refers to Hofstede's cultural dimensions, while academic stress refers to Gadzella's StudentLife Stress Inventory. The questionnaires were randomly distributed to students at Sebelas Maret University, Indonesia and there were 152 students' participants. The class culture indicators were Hofstede's cultural dimensions consist of power distance, collectivism, feminism, uncertainty avoidance, and longterm orientation (Hofstede \& Bond, 1984), on a rating scale of 1-10. The academic stress indicators were pressure, changes, self-imposed, and psychological, emotional and cognitive factors (Gadzella, 1994); using a Likert scale the range of answer choices used was Always, Often, Sometimes, Rarely and Never. To obtain data validity, researcher used content validity. Normality and linearity tests were conducted before performing regression analysis.

Data analysis was conducted using simple regression analysis. The initial stage in simple regression analysis is to know the relationship model between the independent variables and the dependent variable, then test the significance of the relationship model based on the result $p$-value of the analysis of variance (model can be stated statistically significant if $p$-value of .000 $<.05)$.

\section{FINDINGS AND DISCUSSION Findings}

The results of the descriptive analysis presented in Table 1. The skewness index shows a value less than 3 and the kurtosis index shows less than 10 , this indicates that there is a fair level of normality of variables.

Table 1. Results of Descriptive Analysis ( $N=$ 152)

\begin{tabular}{lcccc}
\hline Variable & Mean & $\begin{array}{c}\text { Std } \\
\text { Deviation }\end{array}$ & Skewness & Kurtosis \\
\hline PD & 8.500 & 2.731 & 1.13 & 2.42 \\
CI & 26.382 & 2.013 & .20 & 1.38 \\
FM & 15.645 & 1.533 & -1.06 & 3.52 \\
UAI & 23.763 & 2.134 & .66 & 0.72 \\
LTO & 23.487 & 2.637 & -.53 & 0.31 \\
AS & 35.171 & 5.783 & .35 & .65 \\
\hline
\end{tabular}

Note:

PD : Power Distance (X1)

CI : Collectivism Individualism (X2)

FM : Feminism Masculinity (X3)

UAI : Uncertainty Avoidance (X4)

LTO : Long-Term Orientation (X5)

AS : Academic Stress (Y)

The prerequisite test results indicate that the data are normally distributed and linear. They were analyzed using simple linear regression analysis to test whether there was a partial effect between PD (X1), CI (X2), FM (X3), UAI (X4), LTO (X5) on AS (Y). The results of the data analysis are presented in Table 2.

Table 2. Effects of $X_{1}, X_{2}, X_{3}, X_{4}, X_{5}$, on $Y$

\begin{tabular}{lccccc}
\hline & $\mathbf{X}_{\mathbf{1}}$ & $\mathbf{X}_{2}$ & $\mathbf{X}_{\mathbf{3}}$ & $\mathbf{X}_{\mathbf{4}}$ & $\mathbf{X}_{\mathbf{5}}$ \\
\hline Coef & 29.940 & 51.121 & 45.26 & 22.51 & 52.19 \\
Constant & & & & & \\
Coef & .6155 & -.6046 & -.645 & .982 & -.724 \\
$\mathrm{R}$ & .291 & -.21 & -.17 & .242 & -.33 \\
$\mathrm{R}-\mathrm{Sq}$ & $8.4 \%$ & $4.4 \%$ & $2.9 \%$ & $5.8 \%$ & $10.9 \%$ \\
$\mathrm{~F}$ & 13.84 & 6.96 & 4.51 & 9.32 & 18.37 \\
$\mathrm{p}$-value & .000 & .009 & .035 & .003 & .000 \\
$\mathrm{~N}$ & 152 & 152 & 152 & 152 & 152 \\
\hline
\end{tabular}

\section{Effect of Power Distance on Academic Stress}

The results of the data analysis related to the effect of PD on DNG AS ( $\mathrm{X}_{1}$ on $\left.\mathrm{Y}\right)$ are presented in Table 3. 
Table 3. Effects of $\mathrm{X}_{\mathbf{1}}$ on $\mathrm{Y}$

\begin{tabular}{lcccc}
\hline Reg Equation & $\boldsymbol{R}$ & $\boldsymbol{R}$-sq & $\boldsymbol{F}$ & $\boldsymbol{p}$-value \\
\hline$\hat{\mathrm{Y}}=29.94+.616 \mathrm{X} 1$ & .291 & $8.4 \%$ & 13.84 & .000 \\
$N=152$ & & & & \\
\hline
\end{tabular}

The relationship model between $X_{1}$ and $\mathrm{Y}$ can be expressed in the regression equation. Before being used for predictive purposes, the regression equation model must meet the requirements of linearity and significance, so it was necessary to conduct an F test. Based on the results of the analysis of variance it can be stated that the regression equation model is statistically significant because of $p$-value of $.000<.05$. In other words, the model indicates that if $\mathrm{X}_{1}$ is increased by one point, $\mathrm{Y}$ tends to increase by .616 points at constant 29.94 is linear and meaningful, meaning this regression equation model can be used to predict DNG AS. The analysis also shows a positive correlation coefficient. From this finding it can be concluded that there is a positive and significant influence of PD on AS This means that culture in the class shows that the higher the PD, the higher the AS. The results of the analysis also show that $8.4 \%$ of AS variance was explained by PD. This means that with a good PD, a lower distance of misalignment between lecturers and students will help to minimize AS.

\section{Effect of Collectivism Individualism on Academic Stress}

The results of the data analysis related to the effect of CI on DNG AS ( $\mathrm{X}_{2}$ on $\left.\mathrm{Y}\right)$ are presented in Table 4.

Table 4. Effects of $\mathrm{X}_{2}$ on $\mathrm{Y}$

\begin{tabular}{lcccc}
\hline Reg Equation & $\boldsymbol{R}$ & $\boldsymbol{R}$-sq & $\boldsymbol{F}$ & $\boldsymbol{p}$-value \\
\hline$\hat{\mathrm{Y}}=51.12-.605 \mathrm{X}_{2}$ & -.21 & $4.4 \%$ & 6.96 & .009 \\
$N=152$ & & & & \\
\hline
\end{tabular}

The results of the analysis of variance show that the regression equation model is statistically significant because $p$-value of .009 $<.05$. In other words, the model indicates that if $\mathrm{X}_{2}$ is increased by one point, then $\mathrm{Y}$ tends to fall by .605 points at constant 51.12 , is linear and meaningful, thus DNG AS can be predicted using this regression equation model. The analysis also shows a negative correlation coefficient. From this finding it can thus be concluded that there is a negative and significant effect of $\mathrm{CI}$ on $\mathrm{AS}$
This means that if culture in the class shows a higher CI, the AS will be lower. In addition, the results of the analysis also show that $4.4 \%$ of the AS variance is explained by CI. This means that with a good CI, a higher the value of collectivist culture among students will help to minimize AS.

\section{Effect of Feminism Masculinity on Academic Stress}

The results of the data analysis related to the effect of FM on DNG AS ( $\mathrm{X}_{3}$ on $\left.\mathrm{Y}\right)$ are presented in Table 5 .

Table 5. Effects of $X_{3}$ on $Y$

\begin{tabular}{lcccc}
\hline Reg Equation & $\boldsymbol{R}$ & $\boldsymbol{R}$-sq & $\boldsymbol{F}$ & $\boldsymbol{p}$-value \\
\hline$\hat{\mathrm{Y}}=45.031-.645 \mathrm{X}_{3}$ & -.17 & $2.9 \%$ & 4.51 & .035 \\
$N=152$ & & & & \\
\hline
\end{tabular}

The relationship model between $\mathrm{X}_{3}$ and $\mathrm{Y}$ can be expressed in the regression equation and the results of the analysis of variance show that model was statistically significant because $p$-value of $.035<.05$. In other words, the model indicates that if $X_{3}$ is increased by one point, $\mathrm{Y}$ tends to decrease by .645 points at constant 45.26 , is linear and meaningful; in other words, this regression equation model can be used to predict DNG AS. In addition, the result also shows a negative correlation coefficient. Based on these findings it can thus be concluded that there is a negative and significant influence of FM on AS. This means that if culture in the classroom shows that FM is higher, the lower the AS. The results of the analysis also shows that $2.9 \%$ of AS variance is explained by FM. This means that with a good FM, the higher the cultural value of feminism (that is the perception that gender does not distinguish views) will help to minimize AS.

\section{Effect of Uncertainty Avoidance on Academic Stress}

The results of the data analysis related to the effect of UAI on DNG AS ( $\mathrm{X}_{4}$ on $\left.\mathrm{Y}\right)$ are presented in Table 6 .

Table 6. Effects of $X_{4}$ on $Y$

\begin{tabular}{lcccc}
\hline Reg Equation & $\boldsymbol{R}$ & $\boldsymbol{R}$-sq & $\boldsymbol{F}$ & $\boldsymbol{p}$-value \\
\hline$\hat{\mathrm{Y}}=22.51+.982 \mathrm{X}_{4}$ & .242 & $5.8 \%$ & 9.32 & .003 \\
$N=152$ & & & & \\
\hline
\end{tabular}


The results of the analysis of variance show that the regression equation model is statistically significant because $p$-value of .003 $<.05$. In other words, the model indicates that if $\mathrm{X}_{4}$ is increased by one point, $\mathrm{Y}$ tends to rise by .982 points at constant 22.51 is linear and meaningful; in other words, this model can be used to predict DNG AS. Moreover, the result also shows a positive correlation coefficient. From this finding it can thus be concluded that there is a positive and significant influence of UAI on AS. This means that if culture in the classroom shows a higher UAI, the higher the AS. The analysis also shows that $5.8 \%$ of AS variance is explained by the UAI. This means that with a higher UAI, DNG AS will also be higher, so if the aim is to minimize AS in the learning process a low UAI cultural value should be developed, which is a learning situation that provides space for students to express ideas derived from experimental results or from real experience.

\section{Effect of Long-Term Orientation on Academic Stress}

The results of the data analysis related to the effect of LTO on DNG AS ( $\mathrm{X}_{5}$ on $\left.\mathrm{Y}\right)$ are presented in Table 7.

Table 7. Effects of $X_{5}$ on $Y$

\begin{tabular}{lcccc}
\hline Reg Equation & $\boldsymbol{R}$ & $\boldsymbol{R}-\boldsymbol{s q}$ & $\boldsymbol{F}$ & p-value \\
\hline$\hat{\mathrm{Y}}=52.19-.724 \mathrm{X}_{5}$ & -.33 & $10.9 \%$ & 18.37 & .000 \\
$N=152$ & & & & \\
\hline
\end{tabular}

The results of the analysis of variance show that the relationship model between $\mathrm{X}_{5}$ and $\mathrm{Y}$ was statistically significant because $p$-value of $.000<.05$. In other words, the model indicates that if $\mathrm{X}_{5}$ is increased by one point, $\mathrm{Y}$ tends to fall by .724 points at constant 52.19 , is linear and meaningful, meaning that this equation model can be used to predict DNG AS. Additionally, The analysis also shows a negative correlation coefficient. Therefore, based on these findings it can be concluded that there is a negative and significant effect between LTO and AS. This means that if culture in the class shows a higher LTO, the lower the AS. The analysis also shows that $10.9 \%$ of AS variance is explained by LTO. This means that with a good LTO, a higher level of behaviour that is always oriented to the future will help the DNG to minimize AS.
Based on the results of the data analysis above, the empirical model of the influence of culture in the classroom seen from PD, CI, FM, $\mathrm{UAI}$ and LTO on AS is shown in Figure 1.

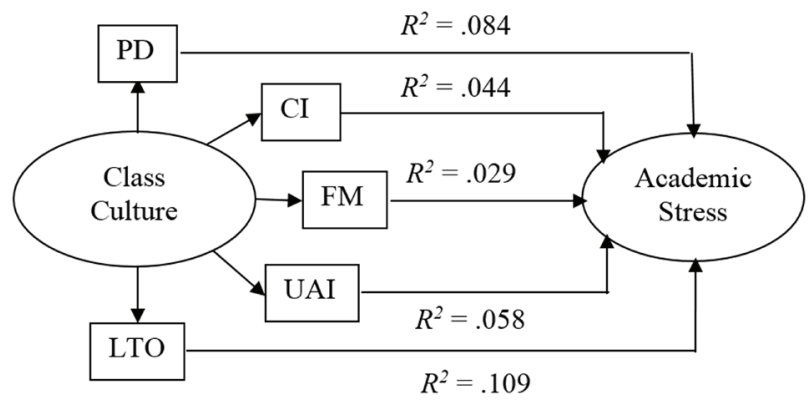

Figure 1. The Empirical Model of the Influence of Culture in the Classroom on AS

\section{Discussion \\ Power Distance has a positive and significant effect on Academic Stress}

The results show that PD had a positive and significant effect on DNG AS, meaning that the higher the PD, the higher the AS. PD in the academic environment is shown by the misalignment between teachers and students (Hofstede \& Bond, 1984). Misalignment in the learning process depends on the learning approach used. High misalignments in the learning process can be seen in the use of the Teacher-Centered Learning (TCL) approach, while low PD can be seen when teachers use the Student-Centered Learning (SCL) approach.

With the TCL approach, the teacher has full control over the continuity of the learning process, so it is not possible for students to express themselves, ask questions or build their own knowledge (Mpho, 2018). The teacher is authoritarian and anti-democratic, producing students who are passive (Serin, 2018); with this approach student tend to be calm, quiet and polite in class because of fear and not because of respect (Mpho, 2018). Conversely, with SCL teachers are more democratic and respect everyone's opinions (Serin, 2018), which creates a conducive atmosphere. If the atmosphere of the learning process in the classroom is conducive, it will create a sense of comfort for students (Prilanita \& Sukirno, 2017).

Thus, it can be concluded that a high level of misalignment between teachers and students will cause students to be afraid or stressed. This 
is consistent with the results of this research, which indicates that $\mathrm{AS}$ will rise if the $\mathrm{PD}$ is higher.

\section{Collectivism Individualism has a Negative and Significant effect on Academic Stress}

The results show that CI had a negative and significant effect on DNG AS, meaning that the higher the collectivism, AS will decrease. This is in line with research by Kormi-Nouri et al. (2015), which shows higher academic stress amongst Swedish students, whose culture tends to be individualistic compared to that of Iranian students, which is more collectivist. Collectivist culture is more socially oriented; that is, it prioritizes the interests of groups, while individualists tend to see themselves as individuals who are able to do things without being dependent on others (Hofstede \& Bond, 1984; Jobson, \& O'Kearney, 2009). In this study, students tended to be depressed when they had to do assignments without the help of friends. Peer acceptance tends to influence student behaviour (Prilanita \& Sukirno 2017). Students feel happy and comfortable discussing with friends when completing assignments, rather than doing it themselves (Kormi-Nouri et al., 2015). The DNG prefers teamwork learning (Prensky, 2001).

Therefore, it can be concluded that the DNG feels more comfortable interacting or discussing with others in order to complete their tasks rather than doing it individually. This is consistent with the results of this research, which indicates that AS will decrease if the collectivist dimension of culture in the learning process is higher.

\section{Feminism Masculinity has a Negative and Significant Effect on Academic Stress}

The results show that FM had a negative and significant effect on DNG AS. Feminism is based on the opinion that gender does not differentiate in terms of views or thoughts, whereas masculinity is indicated by the differences in character and thoughts between men and women (Hofstede \& Bond, 1984). To date, research has shown that men have better views and thoughts than women (Pekkarinen, 2008; Kormi-Nouri et al., 2015). Female students have higher education expectations than men (McDaniel, 2010), so they experience higher academic stress than their male counterparts
(Kormi-Nouri et al., 2015). Although women play more roles and participate in higher education, men have better performance and thoughts than women (Pekkarinen, 2008).

Based on the above studies, men have better views, but this does not happen on the UNS Accounting Education Study Program which has a collectivist culture and almost $90 \%$ of its students are female, even though male students often discuss assignments with females because they are considered to have good views and thoughts in understanding material at learning process. Thus if the cultural dimension of feminism is higher, it means that the higher the culture which considers that gender does not differentiate in terms of views and thoughts, the more DNG AS will decrease.

\section{Uncertainty Avoidance has a Positive and Significant Effect on Academic Stress}

The results show that UAI had a positive and significant effect on DNG AS, meaning that the higher the UAI in a culture, the higher the DNG AS, and vice versa. High UAI refers to the tendency to use laws or regulations to deal with changing situations (Hofstede \& Bond, 1984) and shows a lack of toleration if those who break the rules (House et al., 2004), or see something different as a danger (Joy \& Kolb, 2009). Laws are made with consideration in order to create a structured situation and clear objectives. In the academic environment, a high UAI in culture is shown by the increasing number of students who depend on abstract conceptualization (Joy \& Kolb, 2009) and reflective observation (Yamazaki, 2005). Teachers and students feel more comfortable with structured learning situations with clear goals and schedules (Joy \& Kolb, 2009); they like learning situations with definite answers and appreciate correct answers (Hofstede, 2001). Low UAI tends to be tolerant of breaking rules, willing to take risks (Hofstede \& Bond, 1984), and perceives something different out of curiosity (Joy \& Kolb, 2009). In the academic environment, those with low UAI prefer open learning situations where there is room to express their ideas and learn more easily from real experiences and active experiments (Joy \& Kolb, 2009). The low dimension of UAI culture is consistent with DNG characteristics, which is a preference for informal learning which is not limited by time and space (Prensky, 2001). 
Thus it can be concluded that the DNG feels more comfortable with the creation of a low UAI cultural dimension and are happy if the situation is one of informal learning, with room to express ideas from the results of experiments conducted or from real experiences gained. Feeling happy about the learning situation will minimize student learning problems and lower AS. This is consistent with the results of the study, which indicate that AS will be high if in the learning process the cultural dimension shows high UAI, because such a cultural dimension does not match DNG characteristics. Conversely, if the UAI culture in a class is low, it will decrease AS.

\section{Long-Term Orientation has a Negative and Significant Effect on AS}

LTO is a cultural dimension related to individual involvement in a future-oriented organization, such as planning, investment or delaying individual or collective satisfaction (House et al., 2004). Future-oriented individuals are involved in planning that requires cognitive abilities, are careful in starting new tasks, are willing to take risks, are persistent (Joy \& Kolb, 2009), more innovative and tolerant of change (House et al., 2004). LTO is shown by individuals who think about the longterm consequences if they do something now (Hofstede \& Bond, 1984), and if there is a strong and positive relationship between current tasks and desired future circumstances (House et al., 2004). Individuals who are less oriented towards the future are more focused on the present, and enjoy what they feel now (Hofstede \& Bond, 1984). They may not be able or unwilling to reach their future goals (Joy \& Kolb, 2009).

Therefore, the culture in the classroom that encourages individuals to behave in a futureoriented manner is more innovative and tolerant of change, willing to take risks and if persistent will help students make plans related to what they will do after they finish their studies. Consequently, they will have an overview which is clearly related to the goals that they will achieve through the learning process that they are currently experiencing. This will motivate students to participate in learning, so a higher LTO will minimize DNG AS.

\section{CONCLUSION}

The cultural values that exist in the class that cause the digital native generation (DNG) to feel pressurized or to experience academic stress (AS) are very important to be identified. The causes of academic stress that originate from cultural values in the classroom can be used to determine the values that should be utilized in designing learning models so as to minimize the AS of pre-service accounting teachers. The results show that a higher PD will result in higher AS. A higher CI means a relationship, interaction, cooperation between students the more AS will go down. When the awareness of pre-service accounting teachers regarding gender differences does not differentiate in terms of one's views and thoughts which means the FM is higher, the AS will go down. The higher the UAI which means that the learning situation is structured, rules cannot be tolerated, abstract thinking concepts; such conditions will increase AS. On the contrary, if the UAI culture is reduced (namely the learning situation is more informal, there is room to express ideas, applying experiment-based learning and real experience), such situations will cause a sense of excitement that ultimately decreases AS. Ultimately, the higher the LTO - that is the presence of culture in the classroom stimulates individuals to be future-oriented, innovative thinker, more tolerant of change, willing to take risks and not easily discouraged. It will motivate students to participate in learning that will have an impact on low AS.

The results of this study can be used as a basis for determining methods and content in frameworks for developing learning models for the DNG so as to minimize their learning difficulties or AS. In addition, the study has a limitation as it only focuses on cultural aspects, so in further research it would also be very important to identify other factors that influence DNG AS.

\section{ACKNOWLEDGEMENTS}

The authors would like to thank those who have helped, facilitated and funded this research, especially LPPM UNS, who provided funding through PNBP grants. Thanks also to the Head of Study Program and Lecturers of Accounting 
Education, Faculty of Teacher Training and Education, UNS, and Students who have assisted and facilitated the implementation of the research.

\section{REFERENCES}

Gadzella, B. M. (1994). Student-life stress inventory: Identification of and reactions to stressors. Psychological Reports, 74(2), 395-402. doi:10.2466/pr0.1994.74.2.395.

Gaol, N. T. L. (2016). Teori stres: Stimulus, respons, dan transaksional. [Stress theory: Stimulus, response and transactional]. Buletin Psikologi. 24(1), 1-11. doi:10.22146/bpsi.11224.

Goff, A. M. (2011). Stressor, academic performance, and learned resourcefulness in baccalaureate nursing students. International Journal of Nursing Education Scholarship. 8(1), 1-20. doi:10.2202/1548-923X.2114.

Gufron, A., Budiningsih, C. A., \& Hidayati, H. (2017). Pengembangan pembelajaran berbasis nilai-nilai budaya Yogyakarta di sekolah dasar. [Development of learning based on Yogyakarta cultural values in elementary schools]. Cakrawala Pendidikan, 336(2), 309-319. doi:10.21831/ cp.v36i2.12449.

Gundus, M., Aktepe, V., Sulak, S. E., Baspinar, Z., \& Buyukkarci, E. (2019). Cultural values defining Turkish nation: From the perspectives of history teachers. International Journal of Instruction, 12(22), 193-208. doi:10.29333/ iji.2019.12213a.

Hofstede, G., \& Bond, M. H. (1984). Hofstede's culture dimensions: An independent validation using Rokeach's Value Survey. Journal of Cross-Cultural Psychology, 15(4), 417-433. doi:10.1177/0022002184 015004003.

Hofstede, G. (2001). Culture's consequences: Comparing values, behaviors, institutions, and organizations across nations. Thousand Oaks, CA: Sage Publications.
House, R. J., Hanges, P. J., Javidan, M., Dorfman, P. W., \& Gupta, V. (2004). Culture, leadership and organizations: The GLOBE study of 62 Societies. Thousand Oaks, CA: Sage Publications Inc.

Jobson, L., \& O'Kearney, R. T. (2009). Impact of cultural differences in self on cognitive appraisals in posttraumatic stress disorder. Behavioural and Cognitive Psychotherapy, 37(03), 249-266. doi:10.1017/S135246580900527X.

Joy, S., \& Kolb, D. A. (2009). Are there cultural differences in learning style? International Journal of Intercultural Relations, 33(1), 69-85. doi:10.1016/j.ijintrel.2008.11.002.

Kivunja, C. (2014). Theoretical perspectives of how digital natives learn. International Journal of Higher Education, 3(1), 94109. doi:10.5430/ijhe.v3n1p94.

Kormi-Nouri, R., MacDonald, S., Farahani, M. N., Trost, K., \& Sokri, O. (2015). Academic stress as a health measure and its relationship to patterns of emotion in collectivist and individualist cultures: Similarities and differences. International Journal of Higher Education, 4(2), 92104. doi:10.5430/ijhe.v4n2p92.

Lancaster, L. C., \& Stillman, D. (2002). When generations collide, who they are, why they clash, how to solve the generational puzzle at work. New York, NY: Collins Business.

Lazarus, R. S., \& Folkman, S. (1984). Stress, appraisal, and coping. New York, NY: Springer Publishing Company.

Mpho, O. (2018). Teacher centered dominated approaches: Their implications for today's inclusive classrooms. International Journal of Psychology and Counselling, 10(2), 11-21. doi:10.5897/IJPC2016.0393.

Muslimin, M. (2018). Foster a culture of literacy through increased reading interest in village communities. Cakrawala Pendidikan, 37(1), 107-118. doi:10.21831/cp.v37i1.17141. 
McDaniel, A. (2010). Cross-national gender gaps in educational expectations: The Influence of national-level gender ideology and educational systems. Comparative Education Review, 54(1), 27-50. doi:10.1086/648060.

Mrowka, K. A. K. (2014). Academic stress in an achievement driven era: Time and school culture. (Dissertation, The George Washington University).

Pekkarinen, T. (2008). Gender differences in educational attainment: Evidence on the role of tracking from a Finnish quasiexperiment. Scandinavian Journal of Economics, 110(4), 807-825. doi:10.1111/ j.1467-9442.2008.00562.x.

Prensky, M. (2001). Digital native, digital immigrant. On the Horizon, 9(5), 1-6. doi:10.1108/10748120110424816.

Prilanita, P., \& Sukirno, S. (2017). Peningkatan keterampilan bertanya siswa melalui faktor pembentuknya. [Improved students' questioning skills through their forming factors]. Cakrawala Pendidikan, 36(2), 244256. doi:10.21831/cp.v36i2.11223.

Rochmat, S. (2018). Transformative education as a dialectic of Indonesian culture and modern culture. Cakrawala Pendidikan, $37(3), \quad 366-377 . \quad$ doi:10.21831/ cp.v38i3.21513.

Sandars, J., \& Morrison, C. (2007). What is the net generation? The challenge for future medical education. Medical Teacher, 29(2-3), 85-88. doi:10.1080/01421590601176380.
Sarjou, A. A., Soltani, A., Kalbasi, A., \& Mahmoudi, S. (2012). A study of Iranian students' attitude towards science and technology, school science and environment based on the ROSE Project. Journal of Studies in Education, 2(1), 90103. doi:10.5296/jse.v2i1.1438.

Serin, H. (2018). A comparison of teachercentered and student-centered approaches in educational settings. International Journal of Social Sciences \& Educational Studies, 5(1), 164-167. doi:10.23918/ ijsses.v5i1p164.

Shankar, N. L., \& Park, C. L. (2016). Effects of stress on students' physical and mental health and academic success. International Journal of School \& Educational Psychology, 4(1), 5-9. doi:1 $0.1080 / 21683603.2016 .1130532$.

Talib, N., \& Zia-ur-Rehman, M. (2012). Academic performance and perceived stress among university students. Educational Research and Review, 7(5), 127-132. doi:10.5897/ERR10.192.

Tapscott, D. (2009). Grown up digital: How the net generation is changing your world. New York, NY: McGraw-Hill.

Yamazaki, Y. (2005). Learning styles and typologies of cultural differences: A theoretical and empirical comparison. International Journal of Inter-Cultural Relations, 29(5), 521-548. doi:10.1016/j. ijintrel.2005.07.006. 